\title{
LEVELS OF DEPRESSION AMONG ADOLESCENT GIRLS WITH EARLY MARRIAGE
}

\author{
Lia Yuliana Rachman ${ }^{1}$, Efri Widianti ${ }^{1}$, Anita Setyawati ${ }^{1}$ \\ ${ }^{1}$ Faculty of Nursing, Padjadjaran University, Bandung, Indonesia \\ Corresponding email: liayulianarahman@gmail.com
}

\begin{abstract}
Early marriage encourages various problems for young women. The problems would be affecting their psychological conditions including depression. This study aimed to describe the depression in adolescent girls with early marriage in Babakan Ciparay District, Bandung City. This study was conducted using the descriptive explorative method, with a cross-sectional approach. Samples were selected using the total sampling technique, in which 76 young women aged 16-19 years involved in this study. This study used an instrument from the Indonesian version of the Beck Depression Inventory-II (BDI-II) questionnaire with validity values at $0.361-0.773$ and the value of Cronbach's alpha is 0.898 , and several additional questions related to the problems experienced by girls who married early. The data were analyzed using descriptive statistical analysis techniques for quantitative data and content analysis for interview data. This study was held in the range of April - May 2019. The results showed that $68.4 \%$ of respondents were at a minimum level of depression or did not experience depression, $11.8 \%$ had mild depression, $10.5 \%$ had moderate depression and $9.2 \%$ had severe depression. It can be concluded that the young women did not experience depression, because most respondents married with own desires, lived separately from their parents-in-law and did not experience domestic violence. However, there were still some respondents who are depressed or have the potential to experience depression due to economic problem, problems with in-laws, problems with their husbands and problems related to family relationships. Therefore, there is a need for education about stress management and counseling program to improve the mental health of girls who married early.
\end{abstract}

Keywords: adolescent girl, depression, early marriage

\section{INTRODUCTION}

Early marriage is a formal marriage or informal marriage conducted by an individual before the age of 18 (UNICEF, 2014). One of the regions with the highest prevalence of early marriage in the world is South Asia. Based on these data, Indonesia is one of the countries in South Asia that contributes to the high number of early marriage, in which Indonesia ranks 8th with the condition that one in seven young women in Indonesia conducts early marriage (UNICEF, 2017). One of the provinces in Indonesia with a high rate of early marriage in West Java. This province had ranked 5th of the number of young women who married early (17.28\%) (Badan Pusat Statistik, 2017).

In Bandung City, the number of early marriage has increased. Based on, West Java National Socio-Economic Survey (2016), the percentage of women who were married at less than 16 years of age was $7.82 \%$ and the percentage of women who were married at the age of $17-18$ was $14.92 \%$. In 2017 , the number increased to $8.40 \%$ for women who 
Lia Yuliana Rachman: Levels of Depression among Adolescent Girls

were married at the age of fewer than 16 years and $16.57 \%$ for women who married at the age of 17-18 years. One of the districts in Bandung City that contributes the highest number of early marriage is Babakan Ciparay District with a percentage at 2.98\% (Badan Pusat Statistik, 2017).

Factors that influence immaturity in early marriage decision making include knowledge, education, employment, economic status, income, culture, sexual promiscuity, social media and the role of parents (Aulia, Taufik \& Hastuti, 2013; Pohan, 2017; Wulanuari, A \& Suparman, 2017). This makes early marriage have a greater negative impact on girls who married early, both physically and psychologically. One of the psychological problems that can occur because of early marriage is depression.

Young women who married early are high risks of depression and suicide (Gage, 2013; Nour, 2009; Raj, Gomez, \& Silverman, 2008; Raj, Saggurti, \& Balaiah, 2009). Based on the survey results in India stated that as many as $21 \%$ of participants felt that the detrimental effects of early marriage, in which one of them led to the incidence of depression (Gram Vaani Community, 2013).

Depression in early marriage can be caused by various factors, namely dropping out of school, social isolation, physically and mentally abuse, pregnancy problems, domestic violence, and divorce (Carbone-lópez, 2006; Evenhuis \& Burn, 2014; Guilbert, 2013; Jensen \& Thornton, 2003; John, Edmeades, \& Murithi, 2017; Le Strat, Dubertret, \& Le Foll, 2011; Nour, 2009). In Babakan Ciparay District, two girls had divorced at the age of 19 years. The existence of these findings indicates the possibility of problems that occur in early marriage life. In addition, based on the results of interviews with three adolescent girls who married early in Babakan Ciparay District, there were found some depressive symptoms experienced by them, namely the existence of prolonged sadness and mood disorders. Therefore, this study aimed to describe depressions in adolescent girls with early marriage in Babakan Ciparay District, Bandung City as early detection of the incidence of depression and exploration of problems that occur in adolescent girls who married early.

\section{METHODS}

This study was a descriptive explorative study to identify the level of depression among adolescent girls with early marriage. The samples in this study were 76 adolescent girls aged 16-19 years old from Babakan Ciparay District, Bandung City. The sampling technique in this study was total sampling. The study was conducted in April until May 2019. 
Lia Yuliana Rachman: Levels of Depression among Adolescent Girls

The instrument used in this study was a questionnaire from the Indonesian version of the Beck Depression Inventory-II (BDI-II) (Eysenck, Ginting, Näring, Veld, \& Srisayekti, 2013), and several additional questions related to the problems experienced by girls who married early. The instrument consists of 21 questions about depression symptoms and 10 questions about problems experienced by girls who married early that can encourage depression. This instrument has a validity test value between $0.361-0.773$ and the Cronbach alpha reliability test results is 0.898 .

\section{RESULTS}

Based on table 1, almost half of the adolescent girls with early marriage were 19 years old (43.4\%), and jobless (82.9\%). They married because they wanted to do that $(88.2 \%)$ and they attended junior high school (57.9\%). In addition, the majority of adolescent girls with early marriage live with their nuclear family, 19 people (25\%) live with their husbands and 26 people (34.2\%) live with their husbands and children.

Table 1 Characteristics of Adolescent Girls with Early Marriage (n=76)

\begin{tabular}{|c|c|c|}
\hline Characteristics & $\mathbf{f}(\mathbf{n})$ & $\mathbf{P}(\%)$ \\
\hline \multicolumn{3}{|l|}{ Current age (years) } \\
\hline 16 & 3 & 3.9 \\
\hline 17 & 17 & 22.4 \\
\hline 18 & 23 & 30.3 \\
\hline 19 & 33 & 43.4 \\
\hline \multicolumn{3}{|l|}{ Age at marriage (years) } \\
\hline 14 & 1 & 1.3 \\
\hline 15 & 4 & 5.3 \\
\hline 16 & 30 & 39.5 \\
\hline 17 & 41 & 53.9 \\
\hline \multicolumn{3}{|l|}{ Job } \\
\hline Employee & 13 & 17.1 \\
\hline Jobless & 63 & 82.9 \\
\hline \multicolumn{3}{|l|}{ The person who living together } \\
\hline Husband & 19 & 25.0 \\
\hline Husband and children & 26 & 34.2 \\
\hline Husband and parent & 9 & 11.8 \\
\hline Husband, children, and parent & 8 & 10.5 \\
\hline Husband and parent-in-law & 4 & 5.3 \\
\hline $\begin{array}{l}\text { Husband, children, and parent- } \\
\text { in-law }\end{array}$ & 7 & 9.2 \\
\hline Others & 3 & 3.9 \\
\hline \multicolumn{3}{|l|}{ Reason for marriage } \\
\hline Their desires & 67 & 88.2 \\
\hline Parent & 4 & 5.3 \\
\hline Others (promiscuity) & 5 & 6.6 \\
\hline \multicolumn{3}{|l|}{ Education } \\
\hline Primary school & 24 & 31.6 \\
\hline Junior high school & 44 & 57.9 \\
\hline
\end{tabular}


Table 2 Depression Levels of Adolescent Girls with Early Marriage (n=76)

\begin{tabular}{lcc}
\hline Depression Levels & $\mathbf{f}(\mathbf{n})$ & $\mathbf{P}(\boldsymbol{\%})$ \\
\hline Minimal depression & 52 & 68.4 \\
Mild depression & 9 & 11.8 \\
Moderate depression & 8 & 10.5 \\
Severe depression & 7 & 9.2 \\
\hline
\end{tabular}

Based on table 2, the majority of young women who married early (68.4\%), as many as 52 people were at minimal depression or did not experience depression. While the rest $(31.6 \%)$ were at the level of mild to severe depression.

Table 3 Depression Levels of Adolescent Girls with Early Marriage Based on Factors Encouraging Depression $(n=76)$

\begin{tabular}{|c|c|c|c|c|c|c|c|c|}
\hline \multirow{3}{*}{$\begin{array}{c}\text { Depression } \\
\text { factors }\end{array}$} & \multicolumn{8}{|c|}{ Depression Level } \\
\hline & \multicolumn{2}{|c|}{ Minimal } & \multicolumn{2}{|c|}{ Mild } & \multicolumn{2}{|c|}{ Moderate } & \multicolumn{2}{|c|}{ Severe } \\
\hline & $\mathbf{f}(\mathbf{n})$ & $\mathbf{P}(\%)$ & $\mathbf{f}(\mathbf{n})$ & $\mathbf{P}(\%)$ & $\mathbf{f}(\mathbf{n})$ & $\mathbf{P}(\%)$ & $\mathbf{f}(\mathbf{n})$ & $\mathbf{P}(\%)$ \\
\hline \multicolumn{9}{|l|}{ Physical abuse } \\
\hline Yes & 0 & 0.0 & 1 & 11.1 & 1 & 12.5 & 1 & 14.3 \\
\hline No & 52 & 100 & 8 & 88.9 & 7 & 87.5 & 6 & 85.7 \\
\hline \multicolumn{9}{|c|}{ Bad words from husband or his family } \\
\hline Yes & 3 & 5.8 & 3 & 33.3 & 2 & 25.0 & 2 & 28.6 \\
\hline No & 49 & 94.2 & 6 & 66.7 & 6 & 75.0 & 5 & 71.4 \\
\hline \multicolumn{9}{|c|}{ Not financially supported by husband } \\
\hline Yes & 0 & 0.0 & 0 & 0.0 & 1 & 12.5 & 2 & 28.6 \\
\hline No & 52 & 100 & 9 & 100 & 7 & 87.5 & 5 & 71.4 \\
\hline \multicolumn{9}{|c|}{ Not cared by husband } \\
\hline Yes & 4 & 7.7 & 1 & 11.1 & 2 & 25.0 & 3 & 42.9 \\
\hline No & 48 & 92.3 & 8 & 88.9 & 6 & 75.0 & 4 & 57.1 \\
\hline \multicolumn{9}{|c|}{ Felt excluded by their neighborhood } \\
\hline Yes & 2 & 3.8 & 0 & 0.0 & 3 & 37.5 & 2 & 28.6 \\
\hline No & 50 & 96.2 & 9 & 100 & 5 & 62.5 & 5 & 71.4 \\
\hline \multicolumn{9}{|c|}{ Have friends to tell about their complaints } \\
\hline Yes & 34 & 65.4 & 5 & 55.6 & 4 & 50.0 & 3 & 42.9 \\
\hline No & 18 & 34.6 & 4 & 44.4 & 4 & 50.0 & 4 & 57.1 \\
\hline \multicolumn{9}{|l|}{ Felt alone } \\
\hline Yes & 5 & 9.6 & 3 & 33.3 & 2 & 25.0 & 4 & 57.1 \\
\hline No & 47 & 90.4 & 6 & 66.7 & 6 & 75.0 & 3 & 42.9 \\
\hline
\end{tabular}

Based on table 3, all adolescent girls with early marriages who had physical violence experience from their husbands in the past 3 months were not financially supported. Then, 7 out of 10 adolescent girls who married early received bad words from their husbands or his families, 6 out of 10 people who felt they were not cared for by their 
Lia Yuliana Rachman: Levels of Depression among Adolescent Girls

husbands, 5 out of 7 people who felt excluded by their neighborhood, 12 out of 30 people who felt they did not have friends to tell about their complaints and 9 out of 14 people who felt alone, were depressed from mild to severe levels.

Table 4 Problems Categories Experienced by Adolescent Girls with Early Marriage Based on Interview Results

\begin{tabular}{l}
\hline$\quad$ Problems Categories \\
\hline Economic problem \\
Problems with in-laws \\
Problems with husbands \\
Problems related to family relationships \\
\hline
\end{tabular}

Based on table 4, the categories of the problem are grouped into economic problems, including problems with in-laws, problems with husbands and problems related to family relationships. Economic problem experienced by adolescent girls who married is related to the lack of family income to meet their daily needs. The financial problems made respondents felt sad, anxious, confused, stressed, worried and disappointed. Some adolescent girls who married early said that economic problem was the most severe problems experienced during early married life.

Problems with in-laws experienced by adolescent girls who married early related to discomfort. Adolescent girls who married early confessed that there are things that make them felt offended, resulting in discomfort. The existence of these problems makes adolescent girls who married early felt confused, even one of them claimed to arise the desire to divorce.

Problems with husbands experienced by respondents including quarrels with their husbands, fears of the existence of another people in their marriage life, misunderstanding of their husbands, restraints by their husbands, incompatibility with their husbands and social media problems. Adolescent girls who married early who experience these problems often felt sad, disappointed, scared, nervous, confused, uncomfortable, upset, trying to be patient, anxious and even arise the desire to divorce.

Family relationship problems are husbands who often quarrel with husband's parents and differences of opinion between parents of adolescent girls who married early with their husbands' parents. Adolescent girls who married early who experience this problem claimed to feel sad, anxious, become easily stressed and emotional, and felt confused. 
Lia Yuliana Rachman: Levels of Depression among Adolescent Girls

\section{DISCUSSION}

Based on the results of this study, most adolescent girls who married early did not experience depression. This is in line with previous studies conducted by Lee (2014) in Wausau, United States of America. The results of the study showed that on a measurement scale, all respondents did not experience depression. This can occur due to various factors, including the reasons for marriage, individuals who live together, the absence of driving factors for the occurrence of depression experienced by the majority of respondents, age and the possibility of a good adjustment of the majority of respondents.

According to Casterline (2010, in Guilbert, 2013), the compulsion to conduct marriage makes adolescent girls who married early are more likely to experience depression. However, most of the respondents in this study (89.4\%) did marriage based on their desires, without any coercion from other people, including their parents. Therefore, the risk of experiencing depression would also decrease because of the absence of feeling forced. Homelife will be more comfortable when married couples have their own homes and live freely without any interference from other families. If this is realized, then the psychological needs of each person would be fulfilled. Psychological needs that are fulfilled would improve their psychological well-being, so the risk of depression will decrease. Based on the results of this study, most respondents only lived with their husbands or added their children, so they could reduce the risk of depression because they were free from the interference of others.

According to Carbone-lópez (2006) and UNICEF (2014), the chance of interaction with peers or socializing outside the family unit is one of the factors that influence the occurrence of depression. Adolescent girls who married early who have little chance to socializing increased the risk of depression, anxiety, and suicide. The limited interaction will make them felt alone or lonely. Cacioppo, Hughes, Waite \& Thisted (2006) and Yusuf (2016) state that loneliness contributes more to depression, namely when the high level of loneliness in individuals will be followed by the high level of depression. The results of this study found most adolescent girls who married early have friends to tell stories and not felt alone. This shows that the majority of them can still socialize with friends or relatives, so the risk of depression is reduced.

According to Jain \& Kurz (2007, in Evenhuis \& Burn, 2014), girls who married early are more likely to be physically and mentally abused by their husbands and in-laws. Le Strat et al. (2011) and John et al. (2017) also said that girls who married early had a greater risk of partner violence compared to girls who married at a mature age. Likewise with Jensen \& Thornton (2003) who also said that girls who married early were more 
Lia Yuliana Rachman: Levels of Depression among Adolescent Girls

likely to experience domestic violence. The presence of domestic violence would be affected by their health. However, based on the results of this study, most respondents did not experience physical violence from their husbands, did not get bad words from their husbands or families, cared by their husbands and financially supported by their husbands, so the risk of depression would also decrease due to the low stressors received.

Other factors that might influence the low level of depression in this study are respondents' good adjustment of their marriage life because they were ready to take the risk when deciding to get married early. According to Hurlock (1999), a healthy adjustment will lead to a happy marriage condition. Individuals who fail to adjust will experience conflict in their marriage. While individuals who succeed in adjusting to their married life will experience a harmonious married life. Therefore, the low level of stressors received by most of the respondents in this study and good self-adjustment abilities that may be possessed by adolescent girls who married early can improve psychological well-being, thus avoiding various psychological problems.

In this study, indeed most adolescent girls who married early did not experience depression, but some of them still have depression (31.6\%). This might because of their negative life experience such as physical violence from their husbands, bad words from their husbands or his families, not cared by their husbands, not financially supported by their husbands, ostracized by the neighborhood and not having friends to tell about their complaints. In addition, adolescent girls who married early also experience various problems that can add to their burdens, so they can trigger stress and depression. Based on the results of exploratory studies in this study, these problems included economic problem, problems with in-laws, problems with their husbands and problems related to family relationships.

The economic or financial problem experienced by adolescent girls who married early is the less established economic status of their family. According to John et al. (2017), reduced access to finance is one of the factors that affect the psychological wellbeing of adolescent girls who married early. Therefore, the lack of economy that is owned by adolescent girls who married early can make their psychological well-being decrease, so that it can trigger stress and depression.

In addition, some adolescent girls who married early also experienced several problems such as problems with in-laws, problems with their husbands and problems related to family relationships. These problems are related to inconvenience with in-laws, misunderstandings, and quarrels with husbands, conflicts between adolescent girl's family and their husband family, and others. These problems become psychosocial stressors for 
Lia Yuliana Rachman: Levels of Depression among Adolescent Girls

adolescent girls who married early who can aggravate the burden of life, allowing depression. Previous research conducted by Asmika, Harijanto \& Handayani (2008) states that there is a significant relationship between the level of depression and the level of psychosocial stressors experienced by adolescents. The study was supported by previous research which stated that various types of events experienced by adolescents can be psychosocial stressors that can lead to psychiatric disorders, such as depression (Anisman \& Zacharko, 1992). Therefore, these problems can encourage depression.

Based on this study, most adolescent girls who married early did not experience depression. But there are still some of them who experience depression, even to the level of severe depression. Therefore, it is still necessary to take action from health workers, especially the community health centers or community nurses in the Babakan Ciparay District of Bandung City related to early marriage, both in the prevention of early marriage or services to adolescent girls who married early. In an effort to prevent early marriage, the government has taken various actions, starting from revising the marriage law that sets the minimum age for marriage for men and women to 19 years, conducting early marriage counseling at Islamic boarding schools in West Java, and making programs, Genre (Generasi Berencana) and Youth Information and Counseling Centers, which is spread across schools that focus on educating the public about population control, reproduction, life skills, and youth readiness in families (BKKBN, 2018). However, no intensive efforts have been made on adolescent girls who married early. Therefore, nurses at community health centers or community nurses can be the originators of implementing the program presented by Girls Not Brides (2019), which empowers women, mobilizes families and communities, and provides services to adolescent girls who married early.

The limitation of this study is that the researchers did not succeed in collecting all respondents according to the total population. Of the 85 people who were selected as samples, and finally 76 young women involved in this study. The address of 9 potential respondents was not identified. Another limitation is the questionnaire of this study, specifically about the characteristics of adolescent girls who married early, such as the data about husband's income and residence status have not been listed so that there is still fewer data to be able to discuss more deeply about the results of this study.

\section{CONCLUSION}

Based on this study shows that most adolescent girls who married early did not experience depression. However, there are still some of them who are depressed. Based 
Lia Yuliana Rachman: Levels of Depression among Adolescent Girls

on the results of exploratory studies, the problems experienced by adolescent girls who married early who can encourage depression consist of economic problems, family relations problems, problems with their husbands and problems with in-laws. there is a need for education about stress management and counseling program to improve the mental health of girls who married early.

\section{REFERENCES}

Anisman, H., \& Zacharko. (1992). Depression as a Consequence of Inadequate Neurochemical Adaption in Response to Stressors. British Journal of Psychiatry, $36-43$.

Asmika, Harijanto, \& Handayani, N. (2008). Prevalensi Depresi dan Gambaran Stressor Psikososial Pada Remaja Sekolah Menengah Umum di Wilayah Kotamadya Malang. Jurnal Kedokteran Brawijaya, XXIV(1), 15-22.

Aulia, A., Taufik, M., \& Hastuti, L. (2013). Faktor-faktor yang Mempengaruhi Perkawinan Usia Muda Pada Remaja Putri Usia 10-19 Tahun di Kecamatan Selakau Kabupaten Sambas. Jurnal Mahasiswa Dan Peneliti Kesehatan, 41-53.

Badan Kependudukan dan Keluarga Berencana Nasional (BKKBN). (2018). GENRE GENERASI BERENCANA JEMBATAN MENCIPTAKAN GENERASI MUDA BERKUALITAS. Retrieved from https://www.bkkbn.go.id/detailpost/genregenerasi-berencana-jembatan-menciptakan-generasi-muda-berkualitas

Badan Pusat Statistik. (2017). Statistik Kesejahteraan Rakyat 2017. Jakarta.

Cacioppo, J. T., Hughes, M. E., Waite, L. C., \& Thisted, R. A. (2006). Loneliness as a Spesific Risk Factor for Depresive Symptoms: Cross-sectional and Longitudinal Analyses. Journal Psychology and Aging, 21(1), 140-151.

Carbone-lópez, K. (2006). Patterns of Intimate Partner Violence and Their Associations with Physical Health, Psychological Distress and Substance Use. Public Health Reports, 121, 382-392.

Evenhuis, M., \& Burn, J. (2014). Just Married Just a Child : Child Marriage in The IndoPacific Region. Melbourne.

Eysenck, M. W., Ginting, H., Näring, G., Veld, W. M. Van Der, \& Srisayekti, W. (2013). Validating the Beck Depression Inventory-II in Indonesia's General Population and Coronary Heart Disease Patients. INTERNATIONAL JOURNAL OF CLINICAL AND HEALTH PSYCHOLOGY, 13(3), 235-242. https://doi.org/10.1016/S16972600(13)70028-0

Fitroh, S. F. (2011). Hubungan antara Kematangan Emosi dan Hardness dengan Penyesuaian Diri Menantu Perempuan yang Tinggal di Rumah Ibu Mertua. Jurnal Psikologi Islam, 8(1).

Gage, A. J. (2013). Association of Child Marriage with Suicidal Thoughts and Attempts 
Lia Yuliana Rachman: Levels of Depression among Adolescent Girls

among Adolescent Girls in Ethiopia. Journal of Adolescent Health, 52(654-656).

Girls Not Brides. (2019). HOW CAN WE END CHILD MARRIAGE? Retrieved from https://www.girlsnotbrides.org/how-can-we-end-child-marriage/

Gram Vaani Community. (2013). Early Marriage: a Jharkhand Mobile Vaani Campaign. New Delhi.

Guilbert, N. (2013). Early Marriage, Women Empowerment and Child Mortality: Married Too Young To Be a Good Mother? Retrieved from http://www.dial.ird.fr/content/download/64218/498376/version/1/file/DT+201305+Guilbert.pdf.

Hurlock, E. B. (1999). Psikologi Perkembangan Suatu Pendekatan Sepanjang Rentang Kehidupan (Terjemahan oleh Istiwidayanti dan Soedjarwo). Jakarta: Erlangga.

Jensen, R., \& Thornton, R. (2003). Early Female Marriage in the Developing World. Gender and Development, 11(2), 9-19.

John, N. A., Edmeades, J., \& Murithi, L. (2017). Child Marriage and Psychological Wellbeing in Niger and Ethiopia (Neetu A. John, Jeffrey Edmeades \& Lydia Murithi). Retrieved from https://iussp.confex.com/iussp/ipc2017/mediafile/Presentation/Paper6881/Psywellbe ing_CM_IUSSP_2017.pdf.

Le Strat, Y., Dubertret, C., \& Le Foll, B. (2011). Child Marriage in The United States and Its Association with Mental Health in Women. Pediatrics.

Lee, B. (2014). Adolescent Hmong Marriage \& Risk of Depression. Journal of Student Research, 36-50.

Nour, N. M. (2009). Child Marriage: A Silent Health and Human Rights Issue. Reviews in Obstetrics and Gynecology, 2(1).

Pohan, N. H. (2017). Faktor yang Berhubungan dengan Pernikahan Usia Dini terhadap Remaja Putri. Jurnal Endurance, 2(3), 424-435.

Raj, A., Gomez, C., \& Silverman, J. G. (2008). Driven to a Fiery Death: The Tragedy of Self-Immolation in Afghanistan. New England Journal of Medicine, 358(21), 22012203.

Raj, A., Saggurti, N., \& Balaiah, D. (2009). Prevalence of Child Marriage and Its Effect on Fertility and Fertilitycontrol Outcomes of Young Women in India: a Crosssectional, Observational Study. Lancet.

UNICEF. (2014). Ending Child Marriage: Progress and Prospects. UNICEF.

UNICEF. (2017). Child Marriage Around The World. Retrieved from https://www.girlsnotbrides.org/where-does-it-happen/.

Wulanuari, K. A., A, A. N., \& Suparman. (2017). Faktor-Faktor yang Berhubungan dengan Pernikahan Dini pada Wanita. Jurnal Ners Dan Kebidanan Indonesia, 5(1), $68-75$. 
Lia Yuliana Rachman: Levels of Depression among Adolescent Girls

Yusuf, N. P. (2016). Hubungan Harga Diri dan Kesepian dengan Depresi pada Remaja. In Seminar ASEAN 2nd Psychology \& Humanity, Psychology Forum UMM (pp. 1920). Malang. Retrieved from http://mpsi.umm.ac.id/files/file/386- 393 Nia Paramita Yusuf.pdf 